\title{
Gender on Customer Based Brand Equity: A Case of OK (Bindura) Supermarket
}

\author{
Albert Musekiwa $^{1}$, Langton Runyowa ${ }^{1} \&$ Felix Chikosha ${ }^{1}$ \\ ${ }^{1}$ Marketing Department, Bindura University, Zimbabwe \\ Correspondence: Albert Musekiwa, Marketing Department, Bindura University, P. Bag 1020, Bindura, \\ Zimbabwe. E-mail: musekiwalbert@gmail.com
}

Received: June 5, 2014

Accepted: July 3, $2014 \quad$ Online Published: October 22, 2014

doi:10.5539/ijbm.v9n11p254

URL: http://dx.doi.org/10.5539/ijbm.v9n11p254

\begin{abstract}
In today's competitive environment gender has become a key success factor used in key marketing decision such as segmentation, target marketing and relationship marketing. This study sought to determine if there was difference on supermarket brand equity and its dimensions for OK supermarket Bindura along gender. In absolute terms there was difference between male and female customers when considering means. However, hypotheses test results showed that there was no significant brand equity difference along gender. This was considered to be unsustainable situation when taking into account that female customers were the majority of customers. Consequently, the study recommended that OK stores should intensify marketing efforts towards female customers who formed the majority of its customers.
\end{abstract}

Key words: brand equity, awareness, association, perceived quality, loyalty, gender

\section{Introduction}

There are many brands in Zimbabwe and internationally that carry gender identities such as Truworths Women, Raffels Men, Virginia Slims and Estee Lauder. The importance of gender influence in supermarket brand equity cannot be overemphasised with studies showing that male and female customers are psychologically, physiologically, sociological and culturally different (Frieden, 2013; Fisher \& Dube, 2005). Likewise gender has been found to be important in brand equity dimensions: loyalty, awareness, association and perceived quality (Ye, 2012). A study by Myers-Levy and Maheswaran (1991) found that female customers paid more attention to brand information than male customers and this leads to different levels of brand awareness across gender. Male customers prioritize product quality more than service quality (Gocek et al, 2007; Homburg and Giering, 2001).Therefore the dearth of literature from an African perspective has motivated this study on the role of gender in supermarket brand equity.

\subsection{Background of OK Supermarkets}

OK supermarkets were established in Zimbabwe in 1942. It now operates under four brand names: OK supermarkets, Bon Marche', OK express and OK Mart. OK supermarkets chain targets low to upmarket customers (OK report, 2012). Report by Zimbabwe All Media Products Survey (ZAMPS)) has shown that OK supermarkets dominate the supermarket industry in Zimbabwe (ZAMPS, 2011). It dominates in terms of market coverage and size. The market dominance of OK supermarkets before and after dollarization can largely be attributed to innovation leadership (Reyes, 2005). With dollarization in 2009 the supermarket industry has witnessed the coming in of new big competitors like Pick n Pay which has bought into TM. Likewise the previously small competitors like Food World and Shoppa Stoppa have become big competitors (ZIA report, 2013). Consequently, the increasingly important role played by gender in brand equity which has been highlighted in many studies (Jung and Lee, 2006; Yee, 2008) cannot be overlooked by OK if it wishes to maintain market leadership position in the supermarket industry. This study will therefore become a reference point for decision makers and academics of supermarket industry from an African perspective.

\subsection{Research Problem}

Gender has become the foundation for key marketing decisions such as segmentation, target marketing and relationship marketing. New strong competitors such as Pick n Pay and Shoprite are coming into Zimbabwe. These new entrants who already have competitive advantage of being big players in the industry, more financial 
resources and more expertise can exploit opportunities presented by gender differences through for example segmentation, targeting and positioning and consequently eating into the market share of OK supermarket. Increasingly, this competitive environment calls for OK to have self introspection of its competitive readiness. Therefore, it becomes imperative that this study examines the role of gender in OK supermarket brand equity.

\subsection{Purpose of the Study}

This study seeks to evaluate gender role in customer based brand equity for OK supermarket Bindura.

\subsection{Objectives}

To determine if there is significant difference on brand equity dimensions between female and male customers.

To determine if there is significant difference on brand equity between female and male customers.

\section{Review of Literature}

Keller (1998) defines brand equity as the attitude of consumers towards a brand based on their experiences with the brand. When a firm has strong brand equity it can charge premium prices, attain big market share, extend product lifecycle, attract investors and defend its competitive position (Keller, 1993). The brand equity concept has been supported by models such as Aaker (1991), Keller (1993) the two founding models and Brand asset valuator (2000). The Brand asset valuator model considers five key components of brand equity namely differentiation, energy, relevance, esteem and knowledge. Keller's model has six brand equity building blocks: brand salience, brand performance, brand imagery, brand judgments, brand feelings and brand resonance in order to create significant brand equity. This study will consider Aaker (1991) four dimensions of brand equity: awareness, association, loyalty and perceived quality. The competitive environment that today's retailer is faced with require that successful firms appreciate the distinctiveness between female and male customers, so that they tailor their marketing efforts in accordance with the dictates of the two groups.

\subsection{Gender and Brand Equity}

Gender has been defined as attitudes, feelings and behaviours that a particular culture has towards one's biological sex (American Psychological Association, 2011). Several gender based studies have shown that it is driving force in marketing. Gender has been proved to be important in target marketing (Armstrong et al, 2009; Aziz and Nas 2013) and consumer behaviour (Shohan et al, 1998; Debevec \& Iyer, 1986).

\subsection{Loyalty}

Loyalty refers to commitment to repurchase a particular brand under different situations (Oliver, 1999). Aaker (1991) puts it as attachment customers have with brands. It determines likelihood of brand switching when for example there is a change in price and features. Mittal and Kumakura (2001) espouse that female customers are more brand loyal than male customers. Contrary to this Mautinho and Goode (1995) found that male customers are brand loyal depending on product performance and sales process while female customers have higher dissatisfaction(Bendall-Lyon and Powers, 2002). Far from these views Desmond and Alvin (2005) found that there was insignificant difference in brand loyalty across gender.

\subsection{Awareness}

Kapferer (1997) propagates that awareness is an important dimension found in almost all brand equity models. It has been defined by Keller (2003) as the ability to identify the brand under different conditions linking the brand name, logo; symbol etc to certain associations in memory. Popular brands have more likelihood of being selected over unknown brands. Myers-Levy and Maheswaran (1991) found that female customers paid more attention to brand information than male customers and this leads to different levels of brand awareness across gender. Male customers prefer recognised, fun and functional brands while female customer prefer symbolic benefit brands (Sock \& Bailey, 2008; Andrew, 2002). Female customers have high recall on attractive brand logos while logos that increased recall memory were suitable to males (O’Cass \& Clarke, 2001).

\subsection{Association}

Association refers to brand related information that gives important cues about the brand to consumers (Keller, 2003 and Krishnan, 1996). Associations can either be product or non-product related. Product related associations are based on functional and experiential qualities of the product while non-product related is based on symbolic beliefs obtained from the brandname. Many brands such as Elizabeth Anne and Hugo have gender identities. When a brand is associated with a particular gender, this gives the brand leverage to that gender over other brands (Jung, 2006). 


\subsection{Perceived Quality}

Aaker (1991) reasons that, perceived quality is feelings customers have towards a particular brand. Zeithaml (1988) states that it is consumer's overall judgment of firm's excellence or superiority. Customers depend on perceived quality in judging a product especially when they are not motivated to do a detailed analysis. In supermarkets factors that would determine perceived quality include store design, visuals, customer service and pricing. Customers often use product cues in determining perceived quality. These cues have greater influence on female customer more than male customers. Female customers have a low threshold for elaborating message cues and greater access to the implications of the cues (Myers-Levy \& Sternthal, 1991). Studies have shown that male customers prioritize product quality more than service quality (Gocek et al, 2007; Homburg \& Giering, 2001). Female customers place more emphasis on hygiene and reliability while male customers put it on availability (Oyewole, 2007).

\section{Hypothesis}

The following hypotheses test the significance of the relationships between gender and brand equity.

Gender and brand equity

$\mathrm{H}_{1}$ : There is significant difference between female and male brand equity.

$\mathrm{H}_{1 \mathrm{a}}$ : There is significant difference between female and male customers awareness.

$\mathrm{H}_{1 \mathrm{~b}}$ : There is significant difference between female and male customers perceived quality.

$\mathrm{H}_{1 \mathrm{c}}$ : There is significant difference between female and male customers loyalty.

\section{Methodology}

A descriptive research design was used in this study. Customer based brand equity was broken into: awareness, association, perceived quality and loyalty. Hypothesis was developed and tested between brand equity and its dimensions in accordance with respondent's gender. Respondents were drawn from OK supermarket shoppers. Judgmental sampling was used in selecting the respondents. A sample size of 60 customers was interviewed at the store exit. Five point likert scales was used to gather and analyse the responses. Respondents rated a store on brand equity, awareness, associations, perceived quality and loyalty.

\subsection{Measurement}

The scales were evaluated for validity and reliability. Pearson's correlations were calculated between brand equity and its dimensions. As shown in Table 2 the correlations ranged from 0.78 to 0.89 which is a high positive correlation between brand equity and its dimensions hence the scales were considered valid. Reliability was measured using cronbach alpha and it ranged from 0.73 to 0.92 and retail brand equity had overall cronbach alpha of 0.82 (Table 1). This shows a coefficient exceeding the cut off value of 0.7 recommended by Nunnally (1978) hence reliability was considered high.

\subsection{Correlations Results}

Correlations of brand equity dimensions revealed that awareness and association had a strong positive correlation of 0.8 . For the other dimensions the correlations were weak. As a result association was dropped leaving awareness as suggested by Salkind (2008).

\section{Results}

$\mathrm{H}_{1}$ : There is significant difference between female and male brand equity.

\subsection{Comparing the mean between Male and Female}

For most of brand equity dimensions female customers have higher mean score compared to male customers (see Table 1). The major difference between the means was on perceived quality where it was 0.25 . This shows a wider difference in perceived quality between male and female customers. However for association male customers had higher mean score compared to female customers and it is on this dimension that female customers had the lowest mean score. Male customers had the highest score in awareness while the lowest was on loyalty. Generally, female customers had higher mean scores compared to male customers. 
Table 1. Mean scores

\begin{tabular}{lllll}
\hline & Mean & & SD & \\
& Female & Male & Female & Male \\
\hline Awareness & 3.40 & 3.37 & 0.75 & 0.44 \\
Association & 3.14 & 3.16 & 0.70 & 0.66 \\
Perceived quality & 3.49 & 3.24 & 0.73 & 0.81 \\
Loyalty & 3.19 & 3.13 & 0.95 & 0.64 \\
\hline
\end{tabular}

Table 2. T-test for independent samples

\begin{tabular}{llll}
\hline & T value & Df & Sig.(2 tailed) \\
\hline Brand equity & 0.532 & 58 & 0.597 \\
Awareness & 0.176 & 58 & 0.861 \\
Perceived quality & 1.286 & 58 & 0.204 \\
Loyalty & 0.264 & 58 & 0.793 \\
\hline
\end{tabular}

The $t$ test (see Table 2$)$ results $\left(\mathrm{t}_{58}=0.532, \mathrm{p}=0.597\right)$ show that there is no significant difference between female brand equity and male brand equity thereby disapproving $\mathrm{H}_{1}$. The brand equity of female customers is similar to that of male customers. This can also be seen by the mean brand equity of female customers (3.3) which is almost similar to that of male customers (3.2). It can thus be concluded that there is no significant difference between female and male brand equity. This is supported by the result of brand equity dimensions that awareness $\left(\mathrm{t}_{58}=0.176, \mathrm{p}=0.861\right)$, perceived quality $\left(\mathrm{t}_{58}=1.286, \mathrm{p}=0.204\right)$ and loyalty $\left(\mathrm{t}_{58}=0.264, \mathrm{p}=0.793\right)$ all show there is no significant difference between female and male customers. However perceived quality shows smaller difference with rejection area hence in this there is almost difference. Female customers have a rounded mean score of 4 which means agreed to perceived quality compared to male customers who are not sure.

\section{Discussion}

Comparatively, female customers had higher mean scores compared to male customers on brand equity dimensions implying that female customers had higher brand equity. However, t-test on the significance of the difference along gender showed that on awareness there is no significant difference between male and female customers thereby accepting the null hypothesis. This is contradicts Myers-Levy and Maheswaran (1991) assertion that female customers pay more attention to brand information thereby having more awareness. Similarity in levels of awareness in male and female customers can be attributed to equal exposure to promotional activities by OK supermarkets.

Perceived quality results showed that there is no significant difference between male and female customers although it is important to note that relatively female customers had a high score. Research has shown that both male and female customers are concerned about different quality dimensions. Male customers are concerned about product quality while female customers are concerned about service quality (Gocek et al, 2007; Homburg \& Giering, 2001). Oyewole (2007) concludes that female customers are more concerned with hygiene and reliability while male customers are more concerned with availabity. It is interesting to note that female customers have higher mean score on perceived quality which together with t-test value closer to the rejection area, shows that relatively female customers have higher perceived quality.

The loyalty results concur with observation by Desmond and Goode (1995) that there is no significant difference between male and female loyalty. On the contrary Mittal and Kamakura (2001) concluded that female customers are more loyal while Mautinho and Goode (1995) concluded that male customers are more loyal depending on product performance.

Generally, this study has determined that brand equity and its dimensions both were invariant for female and male customers. Hence it can be concluded that OK supermarkets' endeavour to have brand equity through marketing mix elements received equal acceptance between female and male customers.

\section{Conclusion}

The results showed that there was no significant difference in all equity dimensions along gender. These results show that the brand equity of the female and male customers is similar implying that marketing efforts by OK supermarkets have had equal impact on both female and male customers. Further analysis shows that on perceived quality there was almost significant difference along gender, with female customers having a higher 
score. This showed that improvement in perceived quality dimensions would be highly appreciated by female customers. Additionally, since female customers generally constitute majority of shoppers, the results confirm that the supermarket is not appreciating this contribution as these should be having more brand equity. If female customers continue to have insignificant difference in brand equity with male customers this creates high probability of their turnover in the event of someone coming with more satisfactory service, leading to the store losing its important customer base. This oversight could be caused by OK supermarkets being dependent on mass marketing which unfortunately leaves out female customers. For example the OK Grand Challenge which is the annual major promotion for the store could be alienating female customers because of its highly involving activities such as attending horse racing at Borrowdale race course on a Saturday in Harare and filling of many coupons, which many women because of busy family schedules may end up not participating in. The supermarket should increase its marketing efforts such as advertising, sales promotions, customer service and merchandising with female customers in mind as they are its major customers.

\section{References}

Aaker, D. A. (1991). Managing Brand Equity. New York: The Free Press.

Aaker, D. A. (1996). Building Strong Brands. New York: The Free Press.

American Psychological Association. (2011) http://www.apa.org/pi/lgbt/resources/guidelines.aspx

Retrieved from

Andrew G. P. (2002). Brand choice in gift-giving: Recipient influence. Journal of Product and Brand Management, 11(4), 237-249. http://dx.doi.org/10.1108/10610420210435434

Armstrong, G., Harker, M., Kotler, P., \& Brennan, R. (2009). Marketing: An introduction. European Edition. Harlow: Financial Times Prentice Hall.

Atiligan, E., Aksoy, S., \& Akinci, S. (2005). Determinants of the brand equity: A verification approach in the beverage industry in Turkey. Marketing Intelligence and Planning, 23(3), 237-248. http://dx.doi.org/10.1108/02634500510597283

Aziz, S., \& Nas, Z. (2013). Demographic segmentation and its effects on customer satisfaction. International Journal of Contemporary Business Studies, 4(2), 44-53.

Barwise, P. (1993). Brand equity: Snark or Boojum? International Journal of Marketing Research, 10(March), 93-104. http://dx.doi.org/10.1016/0167-8116(93)90036-X

Bendall-Lyon, D., \& Powers, L. T. L. (2002). The impact of gender differences on change in satisfaction over time. Journal of Consumer Marketing, 19(1), 12-21. http://dx.doi.org/10.1108/07363760210414925

Carpenter, G. S., \& Tybout, A. M. (1998). Meeting the challenge of post modern consumer: Mastering Market Series. Financial Times.

Desmond, C. S. L., \& Alvin, Y. C. L. (2005). The influence of cultural values on brand loyalty. In Consumer Behaviour in 2005 proceedings of the ANZMAC.

Dick, A., \& Basu, K. (1994). Customer Loyalty towards an integrated framework. Journal of the Academy of Marketing Science, 22(2), 99-113. http://dx.doi.org/10.1177/0092070394222001

Fisher, R., \& Dube, L. (2005). Gender differences in responses to emotional advertising: A social desirability perspective. Journal of Consumer Research, 31(4), 850-858. http://dx.doi.org/10.1086/426621

Frieden, L. R. (2013). The role of consumer gender identity and brand concept consistency in evaluating cross gender brand extensions. Retrieved from http://www.scholarcommons.usf.edu/cgi/viewcontents.cgi?article=5685f.context=etd

Gocek, I., Kursun, S., \& Beceren, I. (2007). The perception of customer satisfaction in the textile industry according to gender in Turkey. World Academy of Science, Engineering and Technology, 24, 79-82.

Homburg, C., \& Giering, A. (2001). Personal characteristics as moderators of the relationship between customer satisfaction and loyalty. Psychology and Marketing, 18(1), 43-66. http://dx.doi.org/10.1002/1520-6793(200101)18:1<43::AID-MAR3>3.0.CO;2-I

Jung, K., \& Lee, W. (2006). Cross gender brand extensions: effects of the brand, gender of consumer and product type on evaluation of cross gender extensions. Advances in Consumer Research, 33, 67-74.

Kapferer, J. N. (1997). Strategic Brand Management. London: Kogan Page. 
Keller, K. L. (1998). Strategic brand Management: Building Measuring and Managing Brand equity. Upper saddle River, NJ: Prentice Hall.

Keller, K. L. (2003). Strategic Brand Management. Upper saddle River, NJ: Prentice-Hall.

Keller, M. L. (1993). Conceptualizing, measuring, and managing customer-based brand equity. Journal of Marketing, 57(1), 1-22. http://dx.doi.org/10.2307/1252054

Kim, H. B., \& Kim, W. G. (2004). The effect of consumer-based equity on firmly financial performance. Journal of Consumer Marketing, 20(4), 335-351. http://dx.doi.org/10.1108/07363760310483694

Krishnan, H. S. (1996). Characteristics of memory associations: A consumer-based brand equity perspective. International Journal of Research Marketing, 13(4), 389-405. http://dx.doi.org/10.1016/S0167-8116(96)00021-3

Mautinho, L., \& Goode, M. (1995). Gender effects to the formation of overall product satisfaction: A multivariate approach. Journal of International Consumer Marketing, 8(1), 71-91. http://dx.doi.org/10.1300/J046v08n01_05

Meyers-Levy, J., \& Maheswaran, D. (1991). Exploring differences in males and females' processing strategies. Journal of Consumer Research, 18(1), 63-70. http://dx.doi.org/10.1086/209241

Mittal, V., \& Kamakura, W. (2001). Satisfaction, repurchase intent, and repurchase behaviour: Investigating the moderating effects of customer characteristics. Journal of Marketing Research, 38(1), 131-142. http://dx.doi.org/10.1509/jmkr.38.1.131.18832

Nunnally, J. C. (1978). Psychometric theory (2nd ed.). New York: McGraw-Hill.

O'Cass, A., \& Clarke, P. (2001). Dear Santa, do you have my brand? A study of the brand request styles at Christmas time. Journal of Consumer Behaviour, 2(1), 37-53. http://dx.doi.org/10.1002/cb.88

OK. (2012). OK report. Retrieved from http:// www.okziminvestor.com. Accessed on 12/11/12

Oliver, R .L. (1999). Whence consumer loyalty? Journal of Marketing, 63(special issue), 33-44. http://dx.doi.org/10.2307/1252099

Oyewole, P. (2007). Fast food marketing and the African American consumers: The impact of socio-economic and demographic characteristic. Journal of International Consumer Marketing, 19(4), 75-108. http://dx.doi.org/10.1300/J046v19n04_05

Pappu, R., Quester, P. G., \& Cooksey, R. M. (2005). Consumer based brand equity: improving the measurement-empirical evidence. Journal of Product and Brand Management, 14(3), 143-154. http://dx.doi.org/10.1108/10610420510601012

Reyes, S. (2005). For shoppers, it's love. Brandweek, 46.

Salkind, M. J. (2008). Encyclopaedia of Educational Psychology. London: Sage publications.

Seock, Y. K., \& Bailey L. R. (2008). The influence of college students' shopping orientation and gender differences on online information searches and purchase behaviours. International Journal of Consumer Studies 32(2), 113-121. http://dx.doi.org/10.1111/j.1470-6431.2007.00647.x

Washburn, J. H., \& Plank, R. E. (2002). Measuring brand equity: An evaluation of a consumer-based brand equity scale. Journal of Marketing Theory and Practice, 10(1), 46-62.

Ye, L., \& Pelton, L. E. (2008). The impact of gender effects on consumers' perceptions of brand equity: A cross cultural investigation. University of North Texas.

Yoo, B., Donthu, N., \& Lee, S. C. (2000). An examination of selected marketing mix elements and brand equity. Journal of the Academy of Marketing Science, 28(2), 195-211. http://dx.doi.org/10.1177/0092070300282002

Zeithaml, V. A. (1988). Consumer perceptions of price, quality, and value: A means-end model and synthesis of evidence. Journal of Marketing 52(3), 2-22. http://dx.doi.org/10.2307/1251446

ZIA. (2013). ZIA $2013 . \quad$ report. Retrieved from $\mathrm{http}: / /$ www.zia.co.zw/index.php?option=com_content\&review=article\&id=76:shoppa-stoppa. Accessed

Zimbabwe All Media Products Survey (ZAMPS). (2011). OK dominates as Zimbabwe's preferred retailer. Retrieved from http://www.bizcommunity.com/Article/238/87/56965.htm 


\section{Copyrights}

Copyright for this article is retained by the author(s), with first publication rights granted to the journal.

This is an open-access article distributed under the terms and conditions of the Creative Commons Attribution license (http://creativecommons.org/licenses/by/3.0/). 